\title{
BURNOUT IN THE ANAESTHESIOLOGISTS OF WESTERN UKRAINE AND ITS POSSIBLE CAUSATIVE FACTORS
}

\section{WYPALENIE ZAWODOWE WŚRÓD ANESTEZJOLOGÓW ZACHODNIEJ UKRAINY I POTENCJALNE CZYNNIKI PRZYCZYNIAJĄCE SIĘ DO POWSTAWANIA TEGO ZJAWISKA}

\author{
Oleksandr Oliynyk ${ }^{1(A, C, D, E, F)}$, Anna Ślifirczyk ${ }^{2(C, D)}$, Iryna Prokop ${ }^{1(B)}$, \\ Janina Oliynyk $^{1(B)}$, Olena Venger ${ }^{1(B)}$ \\ ${ }^{1}$ Ivan Horbachevsky Ternopil State Medical University, Ukraine \\ ${ }^{2}$ Pope John Paul II State School of Higher Education in Biała Podlaska, Poland
}

Authors' contribution Wkład autorów:

A. Study design/planning zaplanowanie badań B. Data collection/entry zebranie danych C. Data analysis/statistics dane - analiza i statystyki D. Data interpretation interpretacja danych E. Preparation of manuscript przygotowanie artykułu F. Literature analysis/search wyszukiwanie i analiza literatury G. Funds collection zebranie funduszy
Tables: 3

Figures: 0

References: 15

Submitted: 2018 Oct 11

Accepted: 2018 Oct 26

\section{Summary}

Background. The paper deals with the problem of burnout among the anaesthesiologists of the Western Ukraine region and its causative factors. Burnout is characterized by mental and physical exhaustion owing to prolonged emotional stress.

Material and methods. 105 anaesthesiologists were questioned as to the causes of job-related stress and their personal attitude to the job based on the Maslach Burnout Questionnaire. Questionnaire survey findings were compared in relation to the doctors' practical experience. Results. Burnout symptoms were found to occur in $82 \%$ of anaesthesiologists with practical experience less than 5 years, and in $84 \%$ of doctors with practical experience above 20 years. These groups revealed high values of emotional burnout on the Maslach scale. Anaesthesiologists with 5-20 years of work experience revealed moderate levels of emotional burnout. High level of depersonalization was found in those with 5-20 years of work experience. For doctors who had less than 5 years and more than 20 years of work experience, depersonalization level was moderate.

Conclusions. The group of anaesthesiologists with more than 20 years of work experience had the highest values of professional relationship reduction. The lowest value of this component of burnout was found in the young doctors with work experience of less than 5 years. About $80 \%$ of the doctors pointed out working intensity and insufficient salary as the main causes of work-related stress.

Keywords: burnout syndrome, depersonalization

\section{Streszczenie}

Wprowadzenie. Artykuł przedstawia problem wypalenia zawodowego wśród anestezjologów zachodniej Ukrainy oraz czynniki przyczyniające się do powstawania tego zjawiska. Zespół wypalenia zawodowego charakteryzuje się fizycznym i psychicznym wyczerpaniem wskutek chronicznego napięcia emocjonalnego.

Materiał i metody. W badaniu wzięło udział 105 anestezjologów, którzy odpowiadali na pytania dotyczące stresu związanego z pracą oraz ich postawy wobec pracy z wykorzystaniem kwestionariusza wypalenia zawodowego Christiny Maslach (MBI). Wyniki badań porównano w oparciu o doświadczenie zawodowe lekarzy.

Wyniki. Objawy zespołu wypalenia zawodowego rozpoznano u 82\% anestezjologów pracujacych w zawodzie krócej niż 5 lat oraz u 84\% lekarzy tej specjalności z ponad dwudziestoletnim stażem pracy. Obie grupy cechował wysoki poziom wyczerpania emocjonalnego zgodnie z wynikami na skali MBI (Maslach Burnout Inventory). Anestezjolodzy ze stażem pracy od 5 do 20 lat wykazują umiarkowany poziom wyczerpania emocjonalnego. Wysoki poziom depersonalizacji stwierdzono u lekarzy ze stażem pracy od 5 do 20 lat, natomiast pracujących w zawodzie krócej niż 5 lat oraz dłużej niż 20 lat cechuje umiarkowany poziom depersonalizacji.

Wnioski. Grupę anestezjologów z ponad dwudziestoletnim stażem pracy cechuje najbardziej obniżone zadowolenie z osiagnięć zawodowych. Z kolei ci, którzy pracują w zawodzie najkrócej, mniej niż 5 lat, są najbardziej zadowoleni ze swoich zawodowych osiągnięć. Około 80\% anestezjologów jako główne przyczyny stresu zawodowego wskazuje zbyt dużą intensywność pracy oraz zbyt niskie zarobki.

Słowa kluczowe: zespół wypalenia zawodowego, depersonalizacja

Address for correspondence / Adres korespondencyjny: Oleksandr Oliynyk, Ivan Horbachevsky Ternopil State Medical University, Barvinskih, 5, 46000, Ternopil, Ukraine, e-mail: Alexanderoliynyk8@gmail.com, phone: +38 0632661806, ORCID: Oleksandr Oliynyk https://orcid.org/0000-0003-2886-7741, Anna Ślifirczyk https://orcid.org/0000-0002-2495-025X, Olena Venger https://orcid.org/0000-0002-6847-7206

Copyright: (C) Pope John Paul II State School of Higher Education in Biała Podlaska, Oleksandr Oliynyk, Anna Ślifirczyk, Iryna Prokop, Janina Oliynyk, Olena Venger. This is an Open Access journal, all articles are distributed under the terms of the Creative Commons Attribution-NonCommercial-ShareAlike 4.0 International (CC BY-NC-SA 4.0) License (http://creativecommons.org/licenses/by-nc-sa/4.0/), allowing third parties to copy and redistribute the material in any medium or format and to remix, transform, and build upon the material, provided the original work is properly cited and states its license. 


\section{Introduction}

The Psychiatry Congress in Berlin, 2017 highlighted that work-related stress is a critical problem in the medical field [1]. Declining health due to occupational stress is observed roughly in a third of European Council medical employees, costing an average of 3-4\% of European Council countries' gross national income [2].

Professional and emotional burnout is the most common manifestation of occupational stress, occurring in $30-48 \%$ of medics, and essentially affecting their personal and professional adaptation as well as working selfefficacy [3]. Burnout syndrome has been singled out in the X International Classification of Diseases as a separate diagnostic taxon - Z73 (problems of life management). The term Burnout Syndrome was introduced by an American psychiatrist H.J. Freudenberg in 1974. It characterizes the emotional state of those who communicate intensively in a stressful climate [4]. Extensive research on the phenomenon of burnout had been conducted by Christine Maslach and Susan Jackson [5].

This current study focuses on the assessment of the degree of burnout in the anaesthesiologists of three large hospitals in Ternopil, Ukraine.

\section{Material and methods}

105 anaesthesiologists were divided into 3 age groups depending on their work experience on a speciality: Group 1 - work experience less than 5 years (38 persons); Group 2 - work experience 5-20 years (42 persons); Group 3 - work experience above 20 years (29 persons).

The Maslach burnout questionnaire [6] was used for the calculation of the values of 3 scales: Emotional burnout, Depersonalization, and Reduction of professional achievements. The questionnaire comprises 22 points and pertains to work-related feelings and emotional experiences. Manifestation degree of each statement is assessed on a six-point scale depending on the occurrence, 0 standing for the lack of sensation described; 1 point - for "very seldom"; 2 points - for "seldom"; 3 points - "at times"; 4 points - "often"; 5 points - "very often"; 6 points - "every day".

In addition, the participants completed a questionnaire of five questions concerning the cause of probable job-related stress (see Table 1).

During the statistical processing of the material obtained after the questionnaire by the Maslach scale, the average arithmetic values (M) and the arithmetic mean (m) were calculated.

Table 1. Questionnaire survey of anaesthesiologists as to the causes of job-related stress

\begin{tabular}{|c|c|c|c|}
\hline \multirow{3}{*}{ Question } & \multicolumn{3}{|c|}{ Relative number of participants (\%) who gave positive answers } \\
\hline & \multicolumn{3}{|c|}{ Work experience } \\
\hline & Less than 5 years $(n=38)$ & $5-20$ years $(n=42)$ & Above 20 years $(n=29)$ \\
\hline $\begin{array}{l}\text { The factor ranking first among the } \\
\text { causes of job-related stress: } \\
\text { - Excessive work intensity } \\
\text { - Overtime work } \\
\text { - Enormous occupational } \\
\text { responsibility } \\
\text { - Disparity in one's capabilities } \\
\text { and occupational load }\end{array}$ & $\begin{array}{c}78.90 \\
2.63 \\
7.89 \\
10.53\end{array}$ & $\begin{array}{c}80.95 \\
4.76 \\
\\
9.52 \\
4.76\end{array}$ & $\begin{array}{r}58.62 \\
20.68 \\
20.68 \\
20.68\end{array}$ \\
\hline $\begin{array}{l}\text { Do you regard your speciality as } \\
\text { prestigious? }\end{array}$ & 81.58 & 66.66 & 20.68 \\
\hline Are you satisfied with your salary? & 22.11 & 30.95 & 30.68 \\
\hline Are you financially insecure? & 71.05 & 37.14 & 34.82 \\
\hline $\begin{array}{l}\text { Would you like to change your } \\
\text { profession? }\end{array}$ & 57.89 & 38.09 & 82.75 \\
\hline
\end{tabular}

\section{Results}

To interpret findings, it is necessary to give the values of points which characterize the intensity of burnout syndrome subscales (Table 2) within the study sample. 
Table 2. Values of points which characterize the intensity of burnout syndrome subscales

\begin{tabular}{|c|c|c|c|c|}
\hline Subscale & Low level & Medium level & High level & Maximum \\
\hline $\begin{array}{c}\text { Emotional burnout } \\
\text { (mean - 19.73) }\end{array}$ & $0-15$ & $16-24$ & 25 and more & 54 \\
\hline $\begin{array}{c}\text { Depersonalization } \\
\text { (mean - 7.78) }\end{array}$ & $0-5$ & $6-10$ & 11 and more & 30 \\
\hline $\begin{array}{c}\text { Reduction of professionalism } \\
\text { (mean - 32.93) }\end{array}$ & 37 and more & $31-36$ & 30 and more & 48 \\
\hline
\end{tabular}

Emotional burnout reveals itself in reduced emotional tone, psychotic exhaustion and affective liability, as well as in the loss of interest and positive emotions towards the people around, satiety of work and overall life dissatisfaction.

High values of emotional burnout on the Maslach scale were noted in 2 groups of anaesthesiologists: with less than 5 years practical experience and above 20 years. Those with the work experience within the 5-20 years group revealed a medium level of emotional burnout (Table 3).

In the context of burnout, depersonalization provides for the formation of specific, destructive relations with the people around. Depersonalization involved emotional detachment and indifference, a formal approach to one's professional duties without personal involvement and empathy, and in some cases, negativistic and cynical attitudes towards patients. Behaviourally, depersonalization is manifested in arrogance, use of professional slang, humour, and labelling. High depersonalization level was found in young medics with work experience within 5-20 years; in those with more than 20 years of work experience, depersonalization level was medium.

Table 3. Average scores on factors of Burnout Scale as a function of work experience

\begin{tabular}{|c|c|c|c|}
\hline \multirow{3}{*}{ Constituent of burnout syndrome } & \multicolumn{3}{|c|}{$\begin{array}{l}\text { Average scores for anaesthesiologists according to the burnout syndrome } \\
\text { factors on the Maslach scale }\end{array}$} \\
\hline & \multicolumn{3}{|c|}{ Work experience of participants } \\
\hline & Less than 5 years $(n=38)$ & $5-20$ years $(n=42)$ & Above 20 years $(n=29)$ \\
\hline Emotional burnout & $28.0 \pm 2.6$ & $17.1 \pm 1.5$ & $27.2 \pm 2.3$ \\
\hline Depersonalization & $7.1 \pm 0.6$ & $12.4 \pm 1.1$ & $10.0 \pm 1.1$ \\
\hline $\begin{array}{l}\text { Reduction of professional } \\
\text { achievements }\end{array}$ & $36.2 \pm 2.9$ & $31.0 \pm 2.8$ & $28.2 \pm 2.6$ \\
\hline
\end{tabular}

Reduction of professional achievements reflects the degree of medics' personal and professional satisfaction. High values indicate the tendency to hold a negative assessment of one's competence and productivity leading to reduced professional motivation and an enhancement of a negativistic approach to one's duties, isolation from work colleagues, and detachment and avoidance of work, both psychologically and physically. The doctors with the work experience above 20 years revealed the highest values of professional achievements reduction, whereas the medics with the work experience less than 5 years showed the lowest values.

Additional information was obtained to reveal the causes of burnout in the sample of medics; $76 \%$ of them identified high work intensity as the cause of occupational stress and $12 \%$ identified the disparity in their capabilities and occupational intensity as being a source of stress. As for the latter, the number of anaesthesiologists with more than 20 years of work experience was 4.23 and 1.96 times higher than the number of medics with 5-20 years of work experience and less than 5 years, respectively. With regard to prestige, the number of anaesthesiologists with more than 20 years of work experience who considered their work prestigious was 3.22 times less the amount of those with 5-20 years of experience and 3.94 times less the number of medics with less than 5 years of work experience.

\section{Discussion}

The findings from this study show that being insufficiently compensated, both morally and financially, were two of the main external stress factors in this sample of anaesthesiologists. Among the medics who had more than twenty years of work experience, the number of those who were satisfied with their salary was 1.38 times the number of anaesthesiologists with less than 5 years of work experience. The number of medics who would like to change their occupation is significant $-82.75 \%$ among the doctors with more than 20 years of work experience. The work specifications of anaesthesiologists include: need for prompt and responsible decisionmaking, performance of aggressive manipulations fraught with fatal complications, keeping calm in critical 
clinical situations, intensity of daily working schedule, working in conditions of uncertainty and excessive intensity, handling extremely serious cases, insufficient diagnostic and therapeutic resources alongside with uncertain financial circumstances [7]. In fact, the medic is constantly subjected to psychological traumatic experience including responsibility for the life and health of patients, pressure on the part of patients, their relatives, as well as of colleagues and authorities, and increasing requirements to demonstrate professional competence. This is fraught with physical and mental maladjustment, enhanced social tension and, as a result, declining health [8]. Extreme working conditions also impose stringent requirements on the psychological health status of anaesthesiologists and require the ability to deal with anxiety and depression, high stress immunity, having sufficient social adaptation, and showing the ability to resist occupational burnout [9].

Thus, the following specific occupational stress factors in anaesthesiologists include [9]:

1. responsibility for the life and health of patients,

2. changing situation and need for prompt decision-making (especially in the departments of anaesthesiology and intensive therapy),

3. duration of negative emotions including anguish, pain, despair, etc.,

4. need to maintain high attention focusing and self-control, irrespective of the situation and physiological conditions,

5. irregular working schedule with night and daily shifts,

6. immediate danger from specific patients (criminals, drug addicts, aggressive persons).

These factors are aggravated by unfavourable working conditions [10]:

1. long-term stay (2-12 hours and more) in a confined space (e.g. operating room),

2. long-term stay in a static condition or forced posture,

3. handling psychoactive agents, anaesthetics,

4. risk of contracting infectious diseases,

5. handling medical equipment and instruments.

The high level of emotional burnout observed in this sample of anaesthesiologists is known to be a risk factor of the development of various maladjustment forms at the somatic, behavioural (deviant, addictive behaviour), and psychopathologic level (neuroses, reactive states) [11].

Socio-psychological factors of the anaesthesiologists' work process contribute to the development of chronic stress, underlying professional maladjustment syndrome [12].

Occupational burnout often occurs due to contradictions in professional strategy and tactics, as well as to excessive and unrealizable demands from institutions including the constant burden of liability (material, professional, legal), and an ineffective performance management system.

In similar research conducted in Russia, Netesin and colleagues (2017) found occupational overload in 59\% of anaesthesiologists [13]. In the same study, 63\% of medics considered their speciality prestigious, though $91.7 \%$ were not satisfied with their compensation package. In Russia only $30 \%$ of anaesthesiologists work until their retirement age [15].

According to Maslach [5], burnout is equated with extreme distress and with the $3^{\text {rd }}$ degree of general maladjustment syndrome - exhaustion phase. It is important for anaesthesiologists to show consideration to patients; however, medics experience depersonalization which can lead to a lack of consideration so this is an education issue for the profession. If medics are suffering depersonalization, they can also dehumanize patients leading to less than adequate care. This study shows that this trend can lead to serious problems in the health care management profession. A needy medic can hardly be expected to perform his duties properly. Ukraine is one of a few post-Soviet states with no insurance medicine. As a consequence, the salary of Ukrainian doctors is much lower compared with that of their colleagues in the neighbouring countries.

In summary, it can be said that burnout syndrome in anaesthesiologists develops due to two main factors: high work intensity and low financial interest. Failure to solve the problem results in the impaired health status of medics and in poor work performance. The problem requires a prompt solution primarily through reorganization of the public health system in Ukraine.

\section{Conclusions}

1. High values of emotional burnout on the Maslach scale were revealed in 2 groups of anaesthesiologists: those with the work experience less than 5 years and above 20 years. The medics with 5-20 years of work experience revealed medium burnout.

2. High levels of depersonalization were found in the doctors with 5-20 years of work experience. The medics with less than 5 years and more than 20 years of work experience revealed a medium level of depersonalization. 
3. The highest values of the reduction of professional relations were revealed in the group with more than 20 years of work experience and the lowest values being found in the medics with less than 5 years of work experience.

4. High work intensity and inadequate compensation were the major cause of job-related stress among $80 \%$ of medics.

5. The highest occurrence of professional burnout syndrome among the sample of anaesthesiologists was found in those with less than 5 years and more than 20 years of work experience.

\section{References:}

1. WPA World Psychiatric Association. WPA XVII World Congress of Psychiatry Berlin 2017 [Internet]. Berlin: WPA World Health Association; 2017 [cited 2018 Aug 30]. Available from: https://www.wpaberlin2017.com

2. Sanfilippo F, Noto A, Foresta G. Incidence and factors associated with burnout in anesthesiology: a systematic review. Biomed Res Int. 2017; 2017: 8648925. https://doi.org/10.1155/2017/8648925

3. De Oliveira GS, Chang R, Fitzgerald PC. The prevalence of burnout and depression and their association with adherence to safety and practice standards: a survey of United States anaesthesiology trainees. Anesth Analg. 2013; 117(1): 182-93. https://doi.org/10.1213/ANE.0b013e3182917da9

4. Panagioti M, Panagopoulou E, Bower P. Controlled interventions to reduce burnout in physicians: a systematic review and meta-analysis. JAMA Intern Med. 2017; 177(2): 195-205. https://doi.org/10.1001/jamainternmed.2016.7674

5. Maslach C, Schaufeli WB, Leiter MP. Job burnout. Annu Rev Psychol. 2001; 52: 407-420. https://doi.org/10.1146/annurev.psych.52.1.397

6. Pasikowski T. [Polish adaptation of the Maslach Burnout Inventory Questionnaire]. In: Sęk H., editor. [Occupational burnout: causes, mechanisms, prevention]. Warszawa: PWN; 2000. p. 135-148 (in Polish).

7. De Oliveira GS, Almeida MD, Ahmad S. Anesthesiology residency program director burnout. J Clin Anesth. 2011; 23(3): 176-82. https://doi.org/10.1016/j.jclinane.2011.02.001

8. Embriaco N, Papazian L, Kentish-Barnes N. Burnout syndrome among critical care healthcare workers. Curr Opin Crit Care. 2007; 13(5): 482-8. https://doi.org/10.1097/MCC.0b013e3282efd28a

9. Jakubas-Kolat J. [The phenomenon of stress in the work of the anesthetic team]. Anest Ratow. 2008; 1: 66-69 (in Polish).

10. Dubovik PL, Vartanov VJ, Chlebnikov BA. Burnout syndrome in anesthesiology-reanimatology. Toljatti medical consilium. 2011; 3-4: 34-41.

11. Demerouti E, Bakker AB, Nachreiner F. The job demands-resources model of burnout. J Appl Psychol. 2011; 3: 499-512.

12. Vasilyev VY, Pushkarenko IA. Causes of burnout in anesthesiologists-reanimatologists. Total Reanimatology. $2011 ; 2: 66-73$.

13. Netesin ES, Gorbaczev VI. Burnout syndrome in anesthesiologists and intensive care physicians. VCNC SO RAMS. 2017; 1(113): 74-80.

14. Korehova NG, Soloviov AG. Burnout syndrome in doctors anesthetists. Messenger of Anesthesiology and Resuscitation. 2016; 13(3): 19-25. https://doi.org/10.21292/2078-5658-2016-13-3-19-28

15. Vasiliev VJ, Pushkarenko IA. The reasons of development of burnout syndrome in anesthesiologistreanimatologists. Total Anesthesiology. 2011; 2: 66-73. 